\title{
Cultivation of Critical Thinking Skills in College English Writing under Blended Learning Model
}

\author{
Huijun Fu, Jiancheng Wang \\ Baoding University, Baoding, China \\ Email: fuhuijun@bdu.edu.cn
}

How to cite this paper: Fu, H. J., \& Wang, J. C. (2021). Cultivation of Critical Thinking Skills in College English Writing under Blended Learning Model. Creative Education, 12, 1485-1493.

https://doi.org/10.4236/ce.2021.127113

Received: June 25, 2021

Accepted: July 6, 2021

Published: July 9, 2021

Copyright (อ 2021 by author(s) and Scientific Research Publishing Inc. This work is licensed under the Creative Commons Attribution International License (CC BY 4.0).

http://creativecommons.org/licenses/by/4.0/ (c) (i) Open Access

\begin{abstract}
Critical thinking skills are very important to the cultivation of applied talents. In order to cultivate critical thinking skills in writing of non-English major college students, the research group made detailed investigations on related studies. Then the study analyzed the status quo of college English writing teaching by employing quantitative and qualitative research design. Based on the above study, the research group put forward effective strategies of cultivating critical thinking skills in college English writing under blended learning model. The strategies suggest breaking college English teachers' stereotyped teaching concepts, enhancing their own critical thinking skills, setting up clear teaching objectives, perfecting the teaching process of English writing, optimizing learning resources and establishing a comprehensive evaluation system. The research result can greatly exercise students' judgment and develop their minds, so as to enhance their critical thinking skills and improve the cultivation of talents.
\end{abstract}

\section{Keywords}

Critical Thinking Skills, College English Writing, Blended Learning

\section{Introduction}

With the development of informational technology, blended learning has become a trend in college English teaching. In traditional English classrooms, learners' needs cannot be fully satisfied, and students are lack of interest in the teaching contents. While in online classes, students have too much freedom, some of them lack self-consciousness, and they are not easy to form a systematic understanding of the learning contents. Through combining the traditional English classroom with the online English classroom, blended learning can make up for their respective drawbacks to achieve the optimal teaching effect. Therefore, 
blended learning model has its own advantages.

Critical thinking skills are important skills. Critical thinking skills emphasize independent thinking and are the training goal of college English education. All-round education requires universities to develop students' critical thinking skills. Cultivating students' critical thinking is also in accordance with the goal of talents training of Baoding University. Besides, college English writing as a key skill can reflect students' English proficiency, as well as their communicative competency. To discover whether a student has clear and logical thinking or not, the student's writing can reveal the answer to some extent. College English writing can provide a good opportunity for students to enhance their critical thinking skills.

Therefore, the study will focus on the cultivation of critical thinking skills in college writing under the popular learning model, blended learning model. By means of blended learning model, the study aims to cultivate students' analytical and thinking skills in writing, lead them to express their opinions about certain topics, and make deep reflection and judgment accordingly, thus promoting students' critical thinking skills on the whole.

\section{Literature Review}

Many scholars at home and abroad have studied critical thinking skills. According to Wen et al. (2009), besides meta-critical thinking skills on the higher level, critical thinking skills on the lower level comprise cognitive components and affective components. Cognitive components include cognitive skills and standards which the cognitive skills are supposed to meet. The former involve analysis, inference, and evaluation, while the latter involve clarity, precision, relevance, logic, depth and flexibility. Affective components include curiosity, openness, self-confidence, integrity and perseverance. In the West, research on critical thinking skills has three trends, namely defining critical thinking skills, assessing critical thinking skills, and exploring the ways and effectiveness of the cultivation of critical thinking skills (Wen et al., 2009). Since the 1950s, American educational psychologist Benjamin Bloom has put forward the Taxonomy of Educational Objectives. The third level of the Taxonomy is about the cognitive objective. Lorin Anderson made an improvement to the cognitive objective. Critical thinking skills involve application, analysis, evaluation and creation (Bloom \& Anderson, 1990). Peter A. Facione (1990) gave critical thinking a definition, "We understand critical thinking to be purposeful, self-regulatory judgment which results in interpretation, analysis, evaluation, and inference, as well as explanation of the evidential, conceptual, methodological, criteriological, or contextual considerations upon which that judgment is based." Paul \& Elder held that critical thinking is the ability of an individual to consciously think with appropriate evaluation criteria in order to determine the real value of something and finally make reasonable judgments (Yin, 2004).

Blended learning is the product of science and technology informatization. 
The State Council (2017) issued the $13^{\text {th }}$ Five-Year Plan for the Development of National Education, which stressed integrating information technology with education and teaching, encouraging teachers to make good use of high-quality digital resources in various ways such as blended learning, and forming a new model of ubiquitous online learning that combines online and offline learning. According to $\mathrm{He}$ (2004), blended learning combines the advantages of traditional teaching with network teaching. In blended learning, the teacher plays the leading, inspiring and monitoring role in the teaching process, while students as learning subjects display initiative, enthusiasm and creativity. Singh \& Reed (2001) described blended learning as a learning program where more than one delivery mode is being used with the objective of optimizing the learning outcome and cost of program delivery. It will apply the "right" learning technologies to match the "right" personal learning style to transfer the "right" skills to the "right" person at the "right" time.

Through searching on CNKI (China National Knowledge Infrastructure), there are 27 essays concerning the study of critical thinking of college English writing, which involves the guidance of Production-oriented Approach and the Scaffolding Theory, as well as the application of some platforms, such as Massive Open Online Courses and QQ. However, only one essay studied the exploration and practice of blended teaching mode in college critical writing based on small private online courses (Su, 2020). Although the study employed quantitative research method, it's weak in the study of cultivation strategies of critical thinking skills. There's no related study abroad. Therefore, the study of cultivation of critical thinking skills in college English writing under blended learning model should be paid much attention to.

\section{The Status Quo of College English Writing Teaching}

To objectively investigate the status quo of college English writing teaching, the research group designed the questionnaire (Table 1), which includes 10 questions. Altogether 200 copies of questionnaire were distributed to respondents from Baoding University, Hebei province, China. They major in chemistry, artificial intelligence, history and Chinese language and literature. 50 sophomores were randomly selected from each major as the respondents. After the analysis of data, there were 194 valid copies totally. Meanwhile, an interview (Table 2) involving 7 questions was carried out among 20 college English teachers. The investigation results reveal some defects of the present college English writing teaching.

First, college English writing is not an independent course, as it is integrated into the comprehensive English course. At the same time, English writing is often neglected. 75\% of English teachers take little time dealing with writing tasks. Most of the time, the teaching of college English writing is teacher-centered. They often follow the routine of assigning a writing task and making a brief introduction of the writing topic in the class, and making a brief comment after 
Table 1. The result of the questionnaire (194 valid copies of questionnaire totally).

\begin{tabular}{|c|c|c|c|c|}
\hline Questions & $\begin{array}{c}\text { A } \\
\text { completely } \\
\text { agree }(\mathrm{N})\end{array}$ & $\begin{array}{c}\text { B } \\
\text { agree } \\
(\mathrm{N})\end{array}$ & $\begin{array}{c}\mathrm{C} \\
\text { disagree } \\
(\mathrm{N})\end{array}$ & $\begin{array}{c}\mathrm{D} \\
\text { completely } \\
\text { disagree }(\mathrm{N})\end{array}$ \\
\hline 1. Do you memorize universal writing templates? & 35 & 112 & 34 & 13 \\
\hline 2. Do you often dig into the meaning of the topic? & 12 & 37 & 109 & 36 \\
\hline 3. Do you often discuss the writing topic? & 8 & 81 & 96 & 9 \\
\hline 4. Do you often evaluate your classmates' writing? & 7 & 48 & 118 & 21 \\
\hline 5. Do you like writing? & 12 & 65 & 84 & 33 \\
\hline 6. Do you write for your assignments or CETs? & 105 & 62 & 23 & 4 \\
\hline 7. Do you finish only $2-3$ pieces of writing in one semester? & 53 & 78 & 47 & 16 \\
\hline $\begin{array}{l}\text { 8. Do you just like to read model essays without proper } \\
\text { writing practice? }\end{array}$ & 48 & 95 & 39 & 12 \\
\hline $\begin{array}{l}\text { 9. Do you pay enough attention to the accumulation of } \\
\text { English reading? }\end{array}$ & 17 & 63 & 98 & 16 \\
\hline 10. Have you ever tried the continuation task on iWrite? & 15 & 27 & 54 & 98 \\
\hline
\end{tabular}

Table 2. The result of the interview.

\begin{tabular}{lcc}
\hline \multicolumn{1}{c}{ Questions } & \multicolumn{2}{c}{ Feedbacks } \\
\cline { 2 - 3 } & $\begin{array}{c}\text { Yes } \\
\%(\mathrm{~N})\end{array}$ & $\begin{array}{c}\text { No } \\
\text { \% (N) }\end{array}$ \\
\hline 1. Do you take more time dealing with writing tasks? & $5(25)$ & $15(75)$ \\
2. Do you place importance on the cultivation of language competency? & $100(20)$ & $0(0)$ \\
3. Do you often evaluate the writing content, especially critical thinking? & $35(7)$ & $65(13)$ \\
4. Have you grasped critical thinking skills? & $45(9)$ & $55(11)$ \\
5. Are the writing topics not quite reasonable? & $70(14)$ & $30(6)$ \\
6. Is the utilization of online writing platforms low? & $80(16)$ & $20(4)$ \\
7. Is the self-built item bank of college English writing far from perfect? & $85(17)$ & $15(3)$ \\
\hline
\end{tabular}

class. The time left for students to think over and discuss the writing topic is quite limited. All the college English teachers interviewed (100\%) place importance on the cultivation of language competency such as English vocabulary, grammar, sentence patterns, etc. However, teachers (65\%) don't often evaluate the writing content, especially critical thinking. They tend to neglect the cultivation and training of students' critical thinking skills. Besides, 55\% of English teachers haven't grasped the connotations of critical thinking skills and they lack the related knowledge, which causes them to adopt more mechanical teaching methods and design ineffective critical thinking questions to inspire students in writing teaching.

Second, students adopt inappropriate learning methods for English writing. 147 students ( 35 completely agree; 112 agree) tend to memorize universal writing templates, and apply them mechanically. The writing forms are paid too 
much attention to. However, they (109 disagree; 36 completely disagree) don't often think over the writing topic carefully and dig into the meaning of the topic, which makes the writing quite superficial and lacks logic. Besides, only 89 students (8 completely agree; 81 agree) often discuss a writing topic. 55 students ( 7 completely agree; 48 agree) often make evaluations on their classmates' pieces of writing. As the investigation shows, only a small number of students (12 completely agree; 65 agree) like writing. Many students lack interest in writing. 167 students (105 completely agree; 62 agree) spend their free time writing in English mainly for the purpose of finishing the writing assignment or passing College English Tests (CETs). 131 students (53 completely agree; 78 agree) hold that the output of English writing in one semester is few, with only 2 - 3 pieces of writing. Moreover, 143 students (48 completely agree; 95 agree) just like to read model essays without proper writing practice. These passive ways of learning are not good for them to develop in-depth thinking. Students cannot form their own unique opinions in a coherent way, either. This also runs counter to the goal of talents training of the university. At the same time, 114 students (98 disagree; 16 completely disagree) don't pay enough attention to the accumulation of English reading, which restricts the development of critical thinking skills.

Third, in most cases, the writing topics are recurring and have not been updated in time. 70\% teachers hold that the writing topics are not quite reasonable. The writing topics are mainly from unit topics of college English textbooks and writing topics of CET-4 or CET-6. Sometimes there's a gap between the unit topics and reality. Although writing topics of CETs are relatively new, the amount is limited. Writing platforms provide many writing topics, but available topics are scarcely related to current events. Many of these writing topics are in low value of critical thinking. Besides, pure off-line writing teaching cannot satisfy the demand of enhancing students' critical thinking skills. However, $80 \%$ of teachers hold that the utilization of online writing platforms is low. $85 \%$ of teachers hold that the self-built item bank of college English writing is far from perfect. Although the writing platform of iWrite has a continuing writing function, most students (54 disagree; 98 completely disagree) haven't tried to do the continuation task, thus they cannot meet critical thinking challenges.

Based on the above investigations, it can be seen that the status quo of college English writing teaching is not satisfactory and it presents many problems, especially in the aspect of critical thinking skills. How to enhance critical thinking skills should be the reform direction of college English writing.

\section{Strategies of Cultivating Critical Thinking Skills in College English Writing under Blended Learning Model}

In view of the status quo of college English writing teaching, the research group put forward the following cultivating strategies aiming to promote critical thinking skills in college English writing under blended learning model.

1) College English teachers should break stereotyped teaching concepts, and 
enhance their own critical thinking skills.

College English teaching should not be an exam-oriented education, so college English writing teaching should not be restricted to the writing of college English final exams, CET-4 or CET-6. It should focus on the real improvement of students' writing ability. English teachers should break the traditional writing teaching mode, which tends to emphasize language structures, the proper use of words and some details on the language level but neglect the training of students' critical thinking skills. The stereotyped teaching concepts are not conducive to improving students' writing. English teachers need to realize the importance of critical thinking in English writing teaching, transform the outdated teaching ideas and promote well-rounded education. Meanwhile, with the development of informational technology, English teachers should not purely adopt the traditional off-line teaching model, but the blended teaching model. In this way, teachers can take full advantage of online teaching resources and carry out more effective teaching activities, thus achieving the best effect of the cultivation of critical thinking skills.

Besides, because of years of traditional English writing teaching, English teachers are relatively weak in their own critical thinking skills. As teachers are direct performers of teaching, the level of their critical thinking skills plays a leading role in the overall English writing teaching. In order to ensure high-quality English writing teaching, college English teachers need to improve their own critical thinking skills through reading related books and expanding their own knowledge. They can also regularly participate in some teaching seminars on the cultivation of critical skills, share their teaching experience, prepare for some writing topics and the writing teaching together, etc. Through these activities, English teachers can deepen their understanding of critical thinking skills and strengthen its application. Only by enhancing their own critical thinking skills can they meet the demand of college English writing teaching and cultivate excellent students.

2) Set up clear teaching objectives and perfect the teaching process of English writing.

Although college English writing is not an independent course, it is a part of the College English-Integrated Course, so it is of equal importance as college English reading and should be given enough time to teach. At the same time, college English writing should set up clear teaching objectives. Except for the teaching objectives of language expression, content delivery and inter-cultural communication competence, critical thinking skills should also be placed as one of the objectives of college English writing teaching. The requirements for critical thinking skills have been included in College English Teaching Guidelines (2020 ed.) (The National College Foreign Language Teaching Advisory Board, 2020), in which the fundamental objectives of teaching requirements involve the following: "Students are able to process the language materials of general topics on different occasions, understand the main idea, clarify the facts, viewpoints 
and details, understand others' intentions and attitudes, and then make comprehensive and logical judgments and express basic ideas.", while the development objectives of teaching requirements involve the following: "Students are able to synthesize, compare and analyze information from different sources, objectively examine and evaluate the content of the material, understand the deeper meaning, and draw their own conclusions or form their own understanding."; "Students are able to conduct in-depth communication and discussion on social topics and academic topics related to their major, and effectively describe, state, explain, demonstrate and evaluate them." College English Teaching Guidelines have also pointed out the direction for college English writing teaching. Teachers can train students' critical thinking skills based on those criteria, so as to write thoughtful articles and achieve the real sense of writing.

The teaching process of college English writing should get improved. First, teachers should provide students with some reading materials of critical thinking value in English writing teaching. The reading materials can be seen as the input of language knowledge. While writing, students analyze and think over the reading materials from different perspectives, and then borrow classic sentences or paraphrase valuable opinions from the reading materials, so as to form their own views. In this process, their language and cultural understanding can get enhanced, which helps to develop their ways of thinking. Second, teachers should improve college English writing teaching. The ratio of writing teaching should increase. The teaching should be student-centered. Teachers play the leading role. They need to pay more attention to the interaction with students, encourage students to think actively, and concern about the thought and logic of the writing, thus developing students' critical thinking skills. Writing teaching can be guided by some useful teaching theories such as Production-oriented Approach, the "Continuation" theory, Task-based Language Teaching, etc. Blended learning model should be adopted to make up for the drawbacks of traditional teaching. Online teaching and writing platforms can make the interaction more effective, and provide a large space for students to develop critical thinking skills. Meanwhile, autonomous learning is also encouraged through the application of online learning platforms. Third, teachers should create a relaxed learning atmosphere. As to the learning environment, the layout of tables and chairs in classrooms should be good for communication. In addition, teachers can initiate various activities on learning platforms such as group discussions, brainstorming, drawing mind maps, etc., then students can imagine, show their curiosity or freely express their opinions. Teachers give necessary guidance to make students' critical thinking more relevant and more logical. The relaxed atmosphere can activate students' learning interest, motivation and creativity.

3) Optimize learning resources and establish a comprehensive evaluation system.

In order to provide quality critical thinking materials, college English teachers should optimize learning resources, which include both off-line learning re- 
sources and online learning resources. The learning resources should not be restricted to the writing topics of various exams, but should be closely related to students' daily life and the current hot issues of society. The hot issues are in accord with the diversity and timeliness of the subjects of critical thinking, and also pose challenges to students' critical thinking because those topics are quite new. Students will be more willing to make critical thinking. At the same time, some outdated topics on the learning platforms are of little value and are not helpful to cultivate students' critical thinking skills, so those topics can be deleted. In addition, teachers should devote to constructing a digital repository to enrich and optimize writing resources, thus ensuring the endless supply of high-quality critical thinking materials.

Moreover, college writing teaching should establish a comprehensive evaluation system, which includes formative assessment and summative assessment. Formative assessment emphasizes the assessment of the writing learning process. It mainly relies on the online teaching platform and writing platform. The teaching platform records students' participation in class activities, such as attendances, group discussions, debates, mind mapping, etc. The writing platform mainly records students' writing performances. Formative assessment can take various forms, such as self-assessment, peer revision, teacher evaluation and the automatic evaluation of the writing system. Self-assessment focuses on students' self-reflection, which is beneficial for them to enhance critical thinking skills, so that they can write better and better. Peer revision is helpful for students to discover their advantages as well as disadvantages, such as the writing deficiencies in language forms and critical thinking. It is also a learning process. Teacher evaluation should focus on evaluating the essay structure, inspiring students' wisdom, exploring their thinking, and awakening deep thinking. The automatic evaluation of the writing system can highlight language errors, which prompt students to make constant improvements. As to summative assessment, it refers to the writing task in the final exam or CETs. It can also check students' critical thinking skills. The test results can encourage students to enhance their critical thinking skills.

\section{Conclusion}

The cultivation of critical thinking skills is an important part of college English writing teaching. Critical thinking skills can not only influence the English writing process and writing results, but also reflect students' depth of thinking. Students can exercise good judgment and develop their minds through critical thinking. Besides, with the combination of traditional English learning and e-learning, blended learning model has its unique advantages. It can make full use of all kinds of teaching resources to realize the optimization of the teaching process, thus activating students' learning enthusiasm and creativity. The study focuses on the cultivation of critical thinking skills in college English writing under blended learning model. Through analyzing the status quo of college Eng- 
lish writing teaching, researchers have discovered some problems and put forward effective strategies to solve those problems. The strategies have been applied to the teaching practice of college English writing, and they can also be used for reference by teachers and researchers of other universities. Moreover, constructing the digital repository of critical thinking deserves further study in the near future.

\section{Conflicts of Interest}

The authors declare no conflicts of interest regarding the publication of this paper.

\section{References}

Bloom, B. S., \& Anderson, L. W. (1990). Benjamin and Anderson's Taxonomy. http://www.comp.rgu.ac.uk/staff/sy/PhD Thesis html/page $32 . \mathrm{htm}$

Facione, P. (1990). Delphi Report. http://assessment.ass.duke.edu/documents/Delphi Report.pdf

He, K. K. (2004). The New Development of Educational Technology Theory from Blending Learning. E-Education Research, 3, 1-6.

Singh, H., \& Reed, C. (2001). A Write Paper: Achieving Success with Blended Learning. https://www.docin.com/p-1815130868.html

$\mathrm{Su}$, N. N. (2020). Exploration and Practice of Blended Teaching Mode in College English Critical Writing Based on SPOC. Journal of Inner Mongolia Agricultural University (Social Science Edition), 4, 38-52.

The National College Foreign Language Teaching Advisory Board (2020). College English Teaching Guidelines (2020 ed.). Beijing: Higher Education Press.

The State Council (2017). The 13th Five-Year Plan for the Development of National Education. http://www.gov.cn/zhengce/content/2017-01/19/content 5161341.htm

Wen, Q. F., Wang, J. Q., Zhao, C. R., Liu, Y. P., \& Wang, H. M. (2009). Developing a Conceptual Framework for Assessing Chinese University Students' Critical Thinking Skills. Foreign Language World, 1, 37-43.

Yin, X. F. (2004). A Study on Innovative Textual Reading: A Teaching Pattern and Its Significance. Foreign Languages in China, 1, 41-45. 